\title{
Impact of Integrated E-learning: Traditional Approach to Teaching Engineering Perspective Courses
}

\author{
https://doi.org/10.3991/ijep.v11i2.17777 \\ Lina Nageb Fewella (四) \\ Damietta University, Damietta, Egypt \\ lina.nageb88@gmail.com / linanageb@du.edu.eg \\ Laila Mohamed Khodeir \\ Ain Shams University, Cairo, Egypt \\ Abeer Hamed Swidan \\ Damietta University, Damietta, Egypt
}

\begin{abstract}
The process of teaching engineering perspective courses generally faces a number of challenges due to the nature of the course, the skills required and the large number of students. Thus, this paper aims at assessing the impact of applying a traditional integrated E-learning approach to the teaching of the Engineering Perspective course based on an online system, namely the Google Classroom application. The population of this study is composed of 130 Egyptian first-year applied arts students from the nine departments of the Faculty of Applied Arts at Damietta University during the first semester of the academic year 2019-2020. The sample is determined using Google Forms via Google Classroom. A total of 130 students participated in Google Classroom class and 84 students participated in this investigation. Results revealed that the students primarily preferred the proposed approach for its technical feasibility and its positive effect on their academic performance. Where can they access academic content anytime and anywhere for an infinite number of times? The study resulted in a proposal for a framework designed to apply the integrated approach in a comprehensive manner and adapted to its application in the design of practical engineering courses in which students are enrolled in large numbers.
\end{abstract}

Keywords-Engineering Education, Interactive Technologies, Engineering Perspective, Mobile Learning.

\section{Introduction}

Lectures were the dominant mode of education since the creation of universities for decades [1]. Traditional teachings i.e., based on lectures, are now considered passive modes of instruction because they discourage students from critically reviewing the information provided. Focusing solely on face-to-face interaction does not provide 
space for interactive learning, and does not allow students to develop high-level analytical skills [2]. Technological developments have been critical to teaching and learning strategies in higher education [3]. The rapid development of the demand for Elearning has contributed to a major debate on the effectiveness of interactive learning environments [4]. Distance education is adaptable and web-based, and can be accessed from anywhere and at any time, as long as a device is connected to the Internet [5]. As such, the use of mobile technology to provide, promote and enhance teaching and learning has been defined as E-learning. Cell phone technologies can be integrated into higher education as a new educational approach [6]. The integration of faceto-face approaches will therefore enhance the educational experience that is both interactive and communicative with measurable learning outcomes [2].

This study focuses on the development of the teaching of university engineering courses, and in particular engineering perspective courses. There is now a consensus on the importance of using project-based learning (PBL) and/or other creative pedagogical models in engineering education [7]. In order to identify the appropriate solutions to evaluate the competencies of students and ultimately optimize the training process, engineering schools and universities are regularly challenged to develop innovative teaching approaches. In the engineering curriculum, PBL is usually used because students are especially motivated by the desire to design and construct an end result. The theory of "need to know / need to do" also guides the learning process and encourages students to dig further into ideas [8]. This course is considered a foundation course for students at these colleges and allows the student to identify mass, space and engineering design ratios.

The purpose of this article is to evaluate an attempt to develop traditional methods of teaching this course in order to facilitate its delivery to students. Nonetheless, a new framework of this course has been applied and evaluated by the students in order to improve the pedagogical method of the course. The main objective of improving this course is to provide students with reference files that allow them to complete the learning of what is missed at any given time. This paper examines the impact of applying a traditional integrated E-learning approach to the teaching of the Engineering Perspective (EP) course based on an online system, namely the Google Classroom application (i.e., via smartphones or wireless laptops). This could allow for a much more flexible, step-by-step follow-up of the course, integrated material for both lectures and students. The impact of the proposed teaching approach was evaluated on the case study of the Faculty of Applied Arts of the University of Damietta in Egypt during the first semester of the academic year 2019-2020. To clarify the reason for conducting this study, we discuss the most important challenges facing the teaching of the engineering perspective course and proposals for overcoming these difficulties. How do you overcome the huge number of students in practical engineering courses? How do you communicate easily with a large number of students? What is the simplest way for students to review the steps of drawing? In this article, a proposal is presented to solve these problems using blended learning and student assessment.

The structure of this article is as follows. Section 2 presents a review of the literature. Section 3 presents the methodological aspects of the study. Section 4 presents the results and the main findings are analyzed in Section 5. 


\section{$2 \quad$ Literature Review}

This study is relevant to two areas of study: challenges of teaching engineering perspective course through traditional teaching methods, and the role of interactive teaching techniques in overcoming the challenges. In the next sections we will outline pertinent prior literature in these areas that discussed the research problem.

\subsection{The nature and challenges of traditional teaching an engineering course in higher education}

Teaching the engineering perspective course in engineering colleges faces many difficulties and challenges. One of the most important challenges of this course is that the students need continuous follow-up of the lectures arranged in the course because the nature of the course is a scaffolding one where each step is built upon the next and vice-versa. These challenges can be solved by merging an electronic educational platform that the students and the course professor can communicate through, which can improve the students' accessibility of the course contents to make up for what was missed or needed to be revised. Furthermore, the E-learning and having an online content to the course on web could help when a disaster occurred like corona virus (COVID-19) pandemic which forced the universities to transform most of the work to online strategies applying social spacing to protect themselves against the spread of the pandemic. In an effort to innovate in engineering education and to overcome all the illustrated difficulties, it is necessary to design, implement and provide an Elearning system successfully in such engineering education courses [13]. According to Violante \& Vezzetti, Education also had to develop capabilities reflected in an evergrowing population of students, which occupies places on existing or newly developed courses covering a wide range of subject areas [13]. The implications of these changes increase the student / staff rate, a decrease in student contact hours which, if regular educational practices continued, would lead to a decrease in the learning experience provided. Such conditions on the educational system are clearly associated with the growth and development of computer technology with applications in various fields such as engineering education.

Higher education instructors had been thinking about ideas to make learning process more interactive and stimulating. One familiar approach is to merge an online part with conventional face-to face education [2]. Based on the difficulties that we face in engineering education using traditional methods, a proposal to solve these difficulties is presented. Hence, the project-based learning approach is recognized to be one of the most effective educational way with E-learning platforms [9]. According to Zancul et al., project-based learning approach has an effective role in improving an undergraduate course in new product development [10], [9]. Moreover, design educational systems require planning courses, studio-based courses, or workshops that reflect what design is; how designers think about the future; and how they deal with conflicts, strategy and ethics planning [11].

The engineering perspective course is one of the applied engineering approaches. It aims to enable students enrolled in it to draw external and internal perspectives for 
architectural buildings and interior designs in a realistic engineering way, which enables students to show their ideas and designs in a clearer and attractive way. Such engineering classes begin by understanding how to use the instruments necessary for drawing works. The drawing of a geometrical object is incorporated with the intention of helping the student visualize and draw, as well as learning how to use pencils. Appropriate drawing tools shall be used for the preparing of a clean and accurate drawing [12]. For developing an E-learning framework for engineering education, the indicators of the participants and benefactors of distance learning modules in engineering education should be considered. In addition to providing a bigger understanding of the concepts of learning, educational methods, technology aspect and evaluating which pedagogical approach and communication technologies to be used [13].

\subsection{The role of interactive e-learning techniques in overcoming the challenges}

Universities appeal to broad and varied student audiences; the incorporation of technology-based educational activities in their classes has become essential to the engineering faculty. By understanding how students interact with and use their learning materials, professors will influence their instructional style [3]. This corresponds to what Freeman et al. reported: active learning following guidelines type of students in the learning environment through exercises or discussion in class, as opposed to those passively listening with continuous approach by the teacher [1]. Engineering education is almost still similar to that practiced in the past with the lecture-based approach consisting of presentation and traditional teaching in most engineering courses. Nowadays engineers are facing more complex problems and to find solutions to these problems engineers have to be able to develop their critical thinking skills too [10]. It was mentioned in Khodeir paper that there is a difference between university level engineering - academic achievement and real architecture student expertise [14]. Mixed education or game-based education is an innovative training approach that has been seen to help engineering students' ability to satisfy real business demands and provide them with the so-called employability skills of the 21 st century [14]. The educational methods could be with various mechanisms, such as traditional universities / classrooms, discovery of learning, E-learning, and blended learning. In addition to focusing on the important use of technology in higher education including Elearning which can be adapted to various conditions [16]. Online learning focuses on delivering education to all students who are not physically present in a traditional classroom or university. Incorporating cognitive research through distance education allows to assess human behavior through understanding the modes of learning [17].

To integrate an electronic platform with traditional academic learning, especially in engineering practical subjects, we need the students not only to be recipients, but rather to interact and share their views and inquiries, hence the need for two parts in the proposed system. The first part is for the students to have easy and fast access to the electronic platform, and Google Classroom was a successful option in that, as it is possible to access it for free and through the mobile application or laptop from anywhere. The second part is for the students to be able to interact and communicate with the professor as an organized and rapid manner on the public and private levels. 
Mobile learning (ML) may be a solution to traditional teaching problems in engineering courses. ML is a new trend in the development of E-learning where the users of mobile devices can have access to course materials anywhere and at any time. Using ML system is a bilateral process. Therefore, educators must develop appropriate learning materials besides continuous communication with students. Not only that, but the users of this learning materials have to evaluate the ML system [15]. On another level, Interactive 3D software allows the direct connection of the perceptive motor system to non-physical objects - interactive visual objects. We can, for example, materialize mathematical space using virtual technologies, resolve the learners' difficulties in understanding engineering drawings and the need for mental energy, visual perception and physical coordination needed by engineering drawing, illustrate engineering design principles etc. [13]. So, it could be effective in an engineering perspective course to enhance the educational context.

Abazi-Bexheti et al. tested an educational experience in Learning Management Systems (LMS) about using technology to upgrade learning in HE institutions [18]. The study aimed to analyze the effect of using Google Classroom for the case of South East European University's LMS experience which lasted for more than ten years. Recently, Google Classroom has been proceeded as an LMS solution in the University. The findings showed the students' usage of LMS is affected by level and resources of instructors' LMS usage. Hence, there was a positive relationship between student and instructors' LMS usage. It was a good sign to try Google Classroom as an integrated interactive E-learning platform. On the other hand, Georgieva et al. examined an evaluation of a mobile learning system named FLAGMAN developed in the University of Ruse, Bulgaria [15]. The system aimed to support studying foreign languages by using mobile devices like smart phones or wireless laptops. An investigation was developed for evaluating the system. More than 200 users, students and university lecturers, were asked to fill in the questionnaire after they used the system. The results of the evaluation revealed that the mobile learning system is technically feasible, positively effective in education and easy to use. As such in our proposal, the mobile application was used by most of the students due to the same reasons.

Thus, according to Cestnik et al. smartphone app academic experience called QTvity that the university lecturer can use to prepare questions related to the lecture content is accepted by most learners as a stimulating challenge, especially if their participation is motivated by extra scoring that can enhance their final grades [19]. On another study about the effect of social networking sites on the under-graduated students, it was found that there are many educational dimensions in a huge network such as Blogs, wikis, tweets, discussion boards, podcasts. The study used a demographic segmentation framework was developed to measure the commonly used tools and E-learning technologies. It was revealed that both classroom and social software are the key to producing the student's knowledgeable societies [20]. Bhat et al. stated that classroom instruction can be more effective when being accompanied by technology due to the international demand of technology [21]. These techniques in Elearning are epitomized in Google Suit for Education as it provides a plethora of opportunities for students to discover the multiple options available for them to leverage E-learning. The results of an implemented study to assess the impact of a manual 
compared to an online submission of assignments via Google Classroom revealed an overwhelming success of the online tool. It was easier to follow-up on students' assignments and assess them through E-learning than the manual approach. There was one concern about the originality of the students' work. It could be overcome by the plagiarism check on the assignments. This will not be faced in EP tasks as it is only drawing tasks.

Finally, the educational process must be carried out wisely so as not to reduce the level of quality of learning and teaching, but rather improve it by taking advantage of the possibilities that information and communication technology have provided to the education sector [22]. Videos explaining the steps were a better option than PDF illustrations for they show the techniques provided to learners through the app as an interactive learning environment. Usually, the videos demonstrated what the creativity looked like when mastered, as did the component parts [23]. According to Purg et al. unique cultural and specific professional practices and languages can be eventually adapted to recognize each other's roles and (default) practices, motivating each other to adopt new and non-experienced ways of functioning, thought and interaction [24].

\subsection{The nature of the google classroom application}

Google Apps provide an integrated set of programs that can be used to create an online platform for distance education that consists of free emails and collaborative tools such as G-mail, Google Docs, Google Forms, and Google Presentations for University Education, or large school districts. The most popular Apps / websites that were useful in that trial attempt to improve the engineering education such as Gmail, YouTube, Google Docs, Google Classroom (see Figure 3). Google Classroom can produce, collect and grade assignments for the professor, and provide immediate feedback to students. The professors can use these tools to create an online Learning environment for the students in order to develop self-regulated skills, cooperation, confrontation, discussions and sharing that are all part of the development. All of these skills play an important role in developing the participant's personality, both individually and collectively [26]. Figure 1 shows the most popular Apps / websites that could help in improving the engineering education.

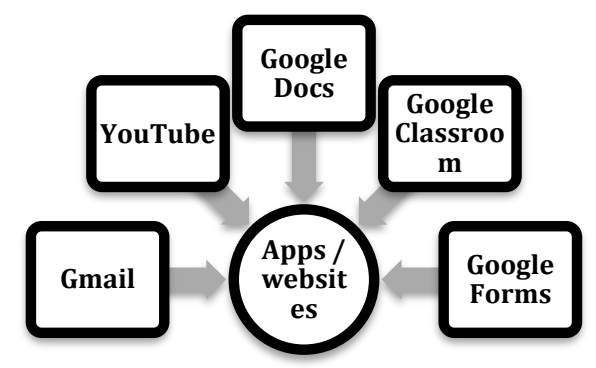

Fig. 1. The most popular Apps / websites that could help in improving the engineering education. 
Google Classroom is a free educational program that integrates e-mails and documents to save into storages. The professors can create a digital classroom for students to communicate with their professors and colleagues. They also can upload files, videos, online links, announcements and assignments for students to review. Document files can be edited in class and shared with colleagues to learn teamwork skills. When students finish an assignment, they can submit by posting on the professor's private board or on the classroom board. This program can be accessed using any device at any place, which is suitable for both professor and students. Google Classroom allows students to chat and discuss topics learned in class, and professors to view student discussion, and post comments. Different assignments can be posted such as videos, PowerPoint presentations, documents and WebQuests [25]. These programs are suitable for adding unlimited numbers of students. Not only that, but these Apps are available on laptops and mobile phones. For example, Google Classroom enables the students to join the course by entering the course code given to them from the lecturer. The system supports different types of materials and interaction: Text, File, Media, Test, Timetable, Workshop.

\section{Methodology}

This study is designed using integrated educational Google Apps that provide an integrated set of programs; these programs can be used to create an online platform for distance education that consists of free emails and collaborative tools. The population in this study is all first-year Egyptian applied arts students; almost one hundred and thirty students who are enrolled in the nine departments of the faculty represented the sample of the study. The case study was evaluated during the first semester of the academic year 2019-2020. The sample is determined using Google Forms via Google Classroom. A total of 130 students have participated in Google Classroom class and 84 students have participated in this investigation.

\subsection{The nature of the developed engineering course on google classroom}

The goal of the course is to present a general base for all the students of different departments in the first year. Hence, the engineering drawing exercises should be used for general engineering block formations. The course content was divided into two parts. The first one was about the instructional material to explain the target of the course. The second part included application materials to practice the course instruction and apply the engineering perspective study. It was an integrated E-learningtraditional approach experience on teaching Engineering Perspective course. The Elearning was an extra supportive approach not the sole style of learning.

\subsection{Course topics}

The professor used Google Classroom to post questions, links, PowerPoints, videos, documents, study guides and tests. Students were accessing online weekly to complete various assignments using Google Classroom. Table 1 presents the fourteenweek Course topics. 
Table 1. Topics from the Engineering Perspective course that was conducted with Google class activities.

\begin{tabular}{|c|c|c|}
\hline Week & Unit and Goal & Google Classroom Activities \\
\hline 1 & $\begin{array}{l}\text { *Introduction to the Engineering Perspective. } \\
\text { *learning about the different types of perspectives. }\end{array}$ & $\begin{array}{l}* \text { Introducing Google Classroom. } \\
* \text { Review Unit Goal and Rubric. } \\
\text { *Publishing an introduction video } \\
\text { about Google Classroom. } \\
* \text { Publishing a video for cube perspec- } \\
\text { tive. } \\
* \text { Publishing the weekly Assignment } \\
\text { drawing task. }\end{array}$ \\
\hline 2 & Theories of two-point perspective drawing. & $\begin{array}{l}* \text { Publishing a video for a simple } 2 \\
\text { boxes perspective. } \\
* \text { Publishing the weekly Assignment } \\
\text { drawing task. }\end{array}$ \\
\hline 3 & $\begin{array}{l}\text { Methods of drawing perspective in several levels } \\
\text { of vision. }\end{array}$ & $\begin{array}{l}\text { * Publishing a video for more compli- } \\
\text { cated boxes perspective. } \\
\text { * Publishing the weekly Assignment } \\
\text { drawing task. }\end{array}$ \\
\hline 4 & Explain shapes, figures and beveled parts. & $\begin{array}{l}\text { * Publishing a video for complicated } \\
\text { boxes with beveled parts perspective. } \\
\text { * Publishing the weekly Assignment } \\
\text { drawing task. }\end{array}$ \\
\hline 5 & $\begin{array}{l}\text { Applications for drawing the engineering perspec- } \\
\text { tive (memorial statue, etc...). }\end{array}$ & $\begin{array}{l}\text { * Publishing a video for memorial } \\
\text { statues perspective. } \\
\text { * Publishing the weekly Assignment } \\
\text { drawing task. }\end{array}$ \\
\hline 6 & $\begin{array}{l}\text { Applications for drawing the engineering perspec- } \\
\text { tive (crossings - entrances ... etc). }\end{array}$ & $\begin{array}{l}\text { * Publishing a video for entrances } \\
\text { perspective. } \\
\text { * Publishing the weekly Assignment } \\
\text { drawing task. }\end{array}$ \\
\hline 7 & Midterm test & Revision \\
\hline 8 & $\begin{array}{l}\text { Geometric perspective of circular cutting in hori- } \\
\text { zontal projection (cone) }\end{array}$ & $\begin{array}{l}\text { * Publishing a video for cone perspec- } \\
\text { tive. } \\
* \text { Publishing the weekly Assignment } \\
\text { drawing task. }\end{array}$ \\
\hline 9 & $\begin{array}{l}\text { Engineering perspective of the circle cutouts in the } \\
\text { horizontal projection (roller) }\end{array}$ & $\begin{array}{l}\text { * Publishing a video for horizontal } \\
\text { circle cutouts in roller perspective. } \\
\text { * Publishing the weekly Assignment } \\
\text { drawing task. }\end{array}$ \\
\hline 10 & $\begin{array}{l}\text { Engineering perspective of the circle cutouts in the } \\
\text { vertical projection }\end{array}$ & $\begin{array}{l}\text { * Publishing a video for vertical circle } \\
\text { cutouts in roller perspective. } \\
\text { * Publishing the weekly Assignment } \\
\text { drawing task. }\end{array}$ \\
\hline 11 & Engineering perspective of the sphere & $\begin{array}{l}\text { * Publishing a video for sphere per- } \\
\text { spective. } \\
* \text { Publishing the weekly Assignment } \\
\text { drawing task. }\end{array}$ \\
\hline 12 & $\begin{array}{l}\text { Applications on drawing the engineering perspec- } \\
\text { tive (various exercises) }\end{array}$ & *General Exercises. \\
\hline 13 & $\begin{array}{l}\text { Applications on drawing the engineering perspec- } \\
\text { tive (various exercises) }\end{array}$ & *General Exercises. \\
\hline 14 & $\begin{array}{l}\text { Applications on drawing the engineering perspec- } \\
\text { tive (various exercises) }\end{array}$ & *General Exercises. \\
\hline
\end{tabular}




\subsection{Setting}

The study started in September 2019 and ended in January 2020, which means 14 weeks to cover the topics on the Engineering Perspective course. It was conducted in the faculty of applied arts, Damietta university in Egypt, and targeted the first-year students from all departments. It took place in a classroom for engineering perspective. An electronic platform was applied in the Engineering Perspective course taught to all departments. This location was chosen because one of the authors is currently employed as a lecturer doctor at the faculty and was the Professor of the targeted course.

\subsection{Participants}

In this study, students of the first year in the Faculty of Applied Arts, Damietta University, Egypt were used as the population. Faculty of Applied Arts, Damietta University has nine majors: (Interior Design and Furniture - Industrial Design - Ceramics - Ornaments - Ready-made garments - Spinning, Weaving and Knitting printing - Advertising - Sculpture, Architectural formation and Restoration - Textile printing, Dyeing and Finishing). A group of students enrolled in the engineering perspective course were chosen as a sample to evaluate the project performance with the requirement that the samples have been using Google Classroom and active in the 2019-2020 semester. After the population selection was done, the number of students participating in the questionnaire was 84 out of 129 students enrolled in the program on classroom.

\subsection{Teaching methods}

In order to achieve new conceptual insights in the production of instructional materials, pedagogical management of the academic approach requires sustainable engagement between teaching and learning topics [27].

Three main educational steps were developed in the proposed integrated educational course. As such, the interactive traditional lecture approach in the faculty, the recorded videos on You tube, the educational materials on Google Classroom and the course Practical work summarize the course teaching methods as shown in Figure 2.

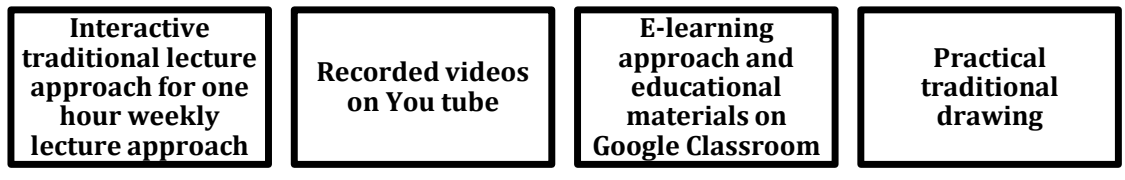

Fig. 2. The applied teaching methods.

According to Richert et al. non-formal educational environments are mostly developed from entertainment modules focused on current virtual worlds. A common result is that in the world of research and higher education, virtual learning environments 
are mostly used and applications like Minecraft are more used in the field of education as well as in that of engineering. Although there have been concerns about whether growing digitalization could threaten the physical existence of universities and the quality of education, as digital technologies have made their way into universities [29]. Nawaila \& Bicen, stated that huge steps have been taken in recent years to combine digital innovation and assistance for education, and these developments have not only affected the educational systems, they have also expanded and questioned our thinking on what defines an educational environment. They are still likely to educate by using two-dimensional technology, which we know is stagnant and does not give a strong content, but because we feel it is more flexible, more helpful and less costly [30]. Achuthan et al., clarified that educational innovations such as virtual worlds are considered as sustainable alternatives to increasing issues related to practical skills training, i.e. the providing of qualitative practical education to a large number of students due to the lack of resources and accessibility, especially in developing countries. The evaluation of its distribution in higher education institutions is important for evaluating its effect, with these virtual environments becoming an advancement for engineering education [31]. Hence, the latest virtual technologies and simulation programs were used in explaining the techniques of the proposed engineering perspective course, which develop the students' imagination, and, in turn, facilitate students' understanding more smoothly and clearly. Figure 3 shows snapshots of their use in illustrating drawings for engineering perspectives.
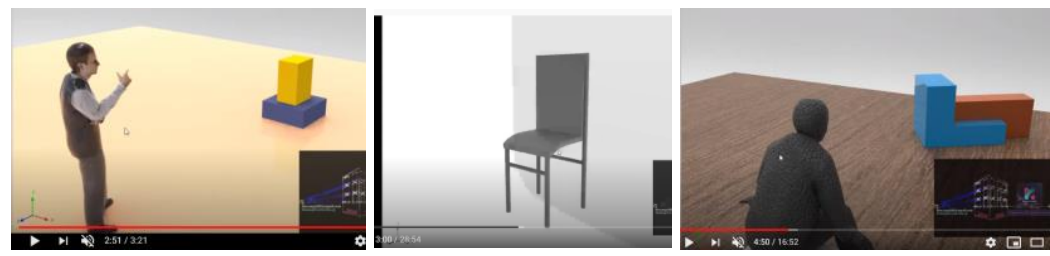

Fig. 3. Shots illustrating the usage of simulation programs in illustrating the course topics [32].

Interactive traditional lecture approach: The Traditional lecture approach of the course was performed in the Faculty of Applied Arts at Damietta University according to the traditional time of the official schedule. The duration was one hour per week according to the regulations of the college attended by students of all scientific departments affiliated to the first year. It was followed by an applying three hours' section per week to each department separately.

Recorded videos on YouTube: The course lectures were uploaded on the YouTube week by week before the official lecture date with the academic schedules as an unlisted link. The lecture video was published for the students on Google Classroom as a scheduled post at a specific time of publishing every week. The videos were placed on the schedule of the course and published automatically one hour after the official traditional lecture time. The advantage of publishing the course materials in unlisted link on YouTube is that no one can see the videos of the course except the one who has the link. Hence, the link was only given to the students who have en- 
rolled in the course, so the number of the videos views is only that of the course students. The number of published sources till this date are 9 videos and the number of published tasks is 8 [33]. The number of students enrolled in the online class is 129 (see Figure 4). The views ranged between $60-400$ in the single video on YouTube among the videos of the course where the enrolled students only had access to the videos of the course.
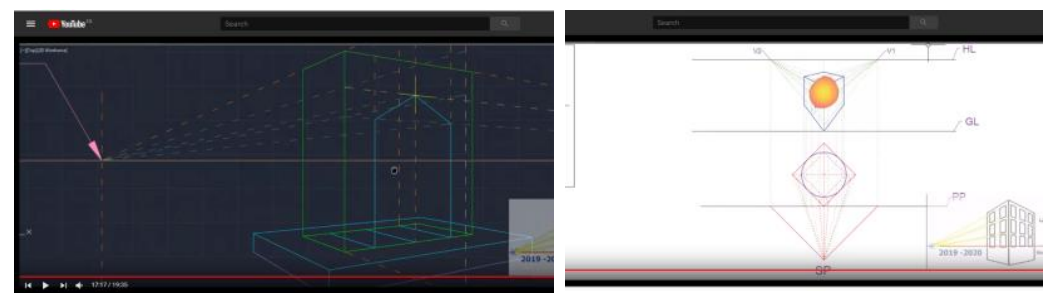

Fig. 4. Sample shots from the online videos of the course [33].

E-learning approach and educational materials on google classroom: A special channel was created for the course on Google Classroom and students were given the channel code to be able to add themselves in the classroom and this system is excellent with large numbers of students as there is no burden on the lecturer when adding enrolled students. Students enrolled in the course on the classroom throughout the first semester while the course was commencing. All lectures and assignments were published on the classroom and students were able to access them continuously during the semester.

Practical traditional drawing: The Practical Work Section drawing is very important to help students applying the instruction of the week lecture into engineering perspective drawings. The applying drawings included three types of tasks (see Figure $5)$.

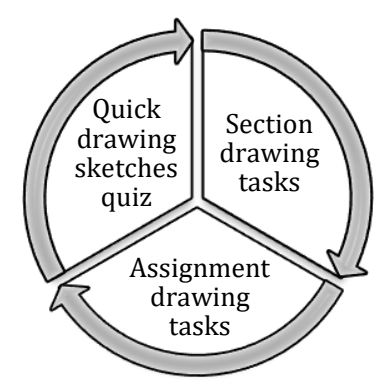

Fig. 5. Tasks carried out during the practical work. 
- Section drawing tasks: The section duration was three hours per week. The student in section drawing a practical task given to them matching what was explained in the lecture and on the online videos by drawing engineering perspectives on the cardboard papers and using the traditional engineering tools.

- Quick drawing sketches quiz: Due to the limited time of the lecture, some quick drawing sketches quizzes were given to the students at the beginning of the lecture.

- Assignment drawing tasks: It is an engineering exercise given to the students to try to solve at home and to be corrected with them in the practical section. Figure 6 shows 6 Samples of students' work who enrolled in The Engineering Perspective academic course 2019 / 2020.

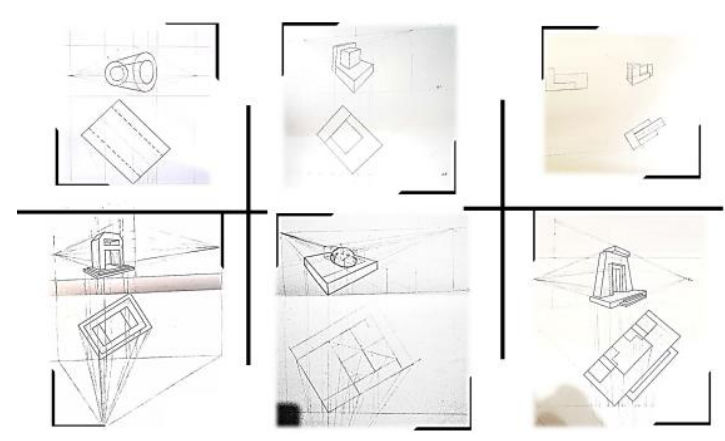

Fig. 6. Samples of engineering perspective tasks done by the enrolled students.

\subsection{The integrated course measuring methods}

In order to measure student's performance and know their satisfaction with the new educational experience, several types of assessment were used. These include a midterm test, final practical exam, quick quiz and survey (see Figure 7).

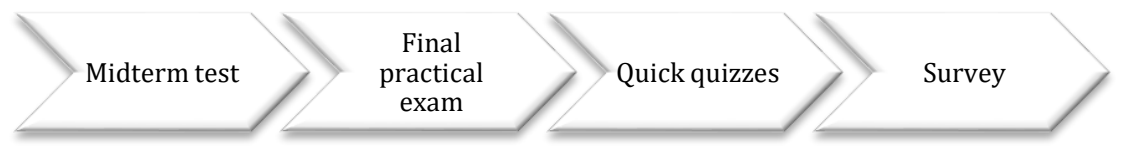

Fig. 7. Student assessment methods in the developed engineering course.

- Midterm test: It was a three hours' traditional practical test on the 7th week of the semester which occurred during the three hours of the section.

- Final practical exam: It was a four hours' traditional practical test at the end of the semester during the Final exams in the Faculty.

- Quick quizzes: This was a ten minutes' quiz done during the traditional Lecture course, three times during the whole semester.

- Student Survey: The survey was performed at the end of the course to measure the student's satisfaction with the new educational experience; it included ten ques- 
tions based on using Google Classroom as an additional approach. The survey was given on Google Forms collecting the students' opinions about the technology usage.

\section{Results and Analyses of the Application of Survey: Measuring Students' Satisfaction}

The Students evaluated the impact of the traditional approach of integrated Elearning on teaching Engineering Perspective course. An online questionnaire consists of 10 questions was developed. The first section contained questions about personal background of the students, while the next ones contained questions about technical feasibility, didactic efficiency, cost effectiveness, user friendliness, device and courseware used, and comments. The evaluation of the system was made during its trials in the faculty of Applied arts, Damietta University in Damietta, Egypt. The users were the first-year students of all nine departments in the faculty who were motivated to use it.

\subsection{The design of the survey questionnaire}

The online survey was developed and analyzed via Google documents and the online link was published on the Google Classroom Engineering Perspective course and sent to all 129 students enrolled in the course. The number of students who responded to the questionnaire was 84 , and the response rate was $65.11 \%$. On Table 2 an illustration of the structures of the survey's ten questions and the methods of answers available to students. The link for Google Classroom Engineering Perspective course is: https://classroom.google.com/c/Mzc5MjMwNTY2NzVa

The link for the online survey which was developed and analyzed via Google documents is: https://docs.google.com/forms/d/e/1FAIpQLSefYHtQNHac-4u36x74Zsy_DgwHfTyCYQ-sqwti8OeVL1PNQ/closedform

Table 2. The structure of the ten survey questions and the response methods available to students.

\begin{tabular}{|c|c|c|c|}
\hline & Questions & $\begin{array}{l}\text { The methods of answers } \\
\text { available to students }\end{array}$ & $\begin{array}{c}\text { The objective of the } \\
\text { question }\end{array}$ \\
\hline- & $\begin{array}{l}\text { Select the department you are } \\
\text { enrolled in. }\end{array}$ & $\begin{array}{l}\text { The supplied answer is a } \\
\text { multiple choice of } 9 \text { depart- } \\
\text { ment. }\end{array}$ & $\begin{array}{l}\text { To clarify whether the } \\
\text { survey participants come } \\
\text { from certain departments } \\
\text { or from all departments }\end{array}$ \\
\hline 1 & $\begin{array}{l}\text { Did you face difficulty down- } \\
\text { loading the free program for } \\
\text { Google Classroom on mobile? }\end{array}$ & $\begin{array}{l}\text { The supplied answer is a } \\
\text { multiple choice of } 3 \text { Evalua- } \\
\text { tion: (Yes - No - Maybe) }\end{array}$ & $\begin{array}{l}\text { Evaluate the ease of the } \\
\text { technology used. }\end{array}$ \\
\hline 2 & $\begin{array}{l}\text { Did you experience difficulty } \\
\text { entering the code for the course } \\
\text { to enter all the educational } \\
\text { media published by the } \\
\text { course's professor? }\end{array}$ & $\begin{array}{l}\text { The supplied answer is a } \\
\text { multiple choice of } 3 \text { Evalua- } \\
\text { tion: (Yes - No- Maybe). }\end{array}$ & $\begin{array}{l}\text { Evaluate the ease of the E- } \\
\text { learning }\end{array}$ \\
\hline 3 & Do you access the program & The answer was made up of & To determine the preferred \\
\hline
\end{tabular}




\begin{tabular}{|c|c|c|c|}
\hline & Questions & $\begin{array}{c}\text { The methods of answers } \\
\text { available to students }\end{array}$ & $\begin{array}{c}\text { The objective of the } \\
\text { question }\end{array}$ \\
\hline & $\begin{array}{l}\text { through the mobile or through } \\
\text { the laptop? }\end{array}$ & $\begin{array}{l}\text { two multiple choices, for the } \\
\text { student to choose one of them } \\
\text { (mobile - laptop). }\end{array}$ & device. \\
\hline 4 & $\begin{array}{l}\text { What is your evaluation of the } \\
\text { extent of commitment and } \\
\text { regularity in the dates of pub- } \\
\text { lishing the scientific material } \\
\text { within the Classroom? }\end{array}$ & $\begin{array}{l}\text { The supplied answer is a } \\
\text { multiple choice of } 4 \text { Evalua- } \\
\text { tion: (Excellent - very good - } \\
\text { good- weak) }\end{array}$ & $\begin{array}{l}\text { Evaluate the effective of } \\
\text { the pre prepared online } \\
\text { schedule lecture. }\end{array}$ \\
\hline 5 & $\begin{array}{l}\text { How effective was the method } \\
\text { of solving engineering exercis- } \\
\text { es recorded in videos and } \\
\text { posted online on the same day } \\
\text { of the lecture? }\end{array}$ & $\begin{array}{l}\text { The supplied answer is a } \\
\text { multiple choice of } 4 \text { Evalua- } \\
\text { tion: (Excellent - medium - } \\
\text { accepted- weak) }\end{array}$ & $\begin{array}{l}\text { Evaluate the effective of } \\
\text { the new style of learning. }\end{array}$ \\
\hline 6 & $\begin{array}{l}\text { How responsive and interactive } \\
\text { is the lecturer to the students' } \\
\text { proposals? }\end{array}$ & $\begin{array}{l}\text { The supplied answer is a } \\
\text { multiple choice of } 4 \text { Evalua- } \\
\text { tion: (Excellent - very good - } \\
\text { good- weak) }\end{array}$ & $\begin{array}{l}\text { Evaluate the professor } \\
\text { response. }\end{array}$ \\
\hline 7 & $\begin{array}{l}\text { Did you face difficulties when } \\
\text { dealing with the application on } \\
\text { the mobile phone and when } \\
\text { learning about the program? }\end{array}$ & $\begin{array}{l}\text { The supplied answer is a } \\
\text { multiple choice of } 2 \text { Evalua- } \\
\text { tion: (Yes - No). }\end{array}$ & $\begin{array}{l}\text { Evaluate the student's } \\
\text { response to the program. }\end{array}$ \\
\hline 8 & $\begin{array}{l}\text { Do you propose to generalize } \\
\text { this experience again and in } \\
\text { other courses? }\end{array}$ & $\begin{array}{l}\text { The supplied answer is a } \\
\text { multiple choice of } 3 \text { Evalua- } \\
\text { tion: (Strongly suggested - } \\
\text { suggested with amendment - } \\
\text { not suggested). }\end{array}$ & $\begin{array}{l}\text { Evaluate the Students' } \\
\text { opinions on generalizing } \\
\text { this experience. }\end{array}$ \\
\hline 9 & $\begin{array}{l}\text { A short answer question about } \\
\text { the student's opinion on this } \\
\text { new experience. }\end{array}$ & $\begin{array}{l}\text { A short answer space was } \\
\text { provided }\end{array}$ & $\begin{array}{l}\text { Knowing students' opin- } \\
\text { ions and suggestions }\end{array}$ \\
\hline 10 & $\begin{array}{l}\text { Is the lecture alone sufficient, } \\
\text { or is the presence of the appli- } \\
\text { cation a good support for the } \\
\text { lecture? }\end{array}$ & $\begin{array}{l}\text { The supplied answer is a } \\
\text { multiple choice of } 4 \text { pro- } \\
\text { posals: } \\
\text { *The lecture alone is suffi- } \\
\text { cient. } \\
* \text { the application alone is } \\
\text { sufficient. } \\
* \text { the integrated system via } \\
\text { the traditional lectures and } \\
\text { application } \\
\text { *other proposals }\end{array}$ & $\begin{array}{l}\text { Knowing student opinions } \\
\text { when using Google Class- } \\
\text { room as a temporary } \\
\text { method alone to receive } \\
\text { course lectures }\end{array}$ \\
\hline
\end{tabular}

\subsection{Analysis of survey responses throughout the course}

The survey was sent to all 129 students enrolled in the course. The number of students who responded to the questionnaire was 84 from all the different departments, and the response rate was $65.11 \%$ (see Figure 8). 


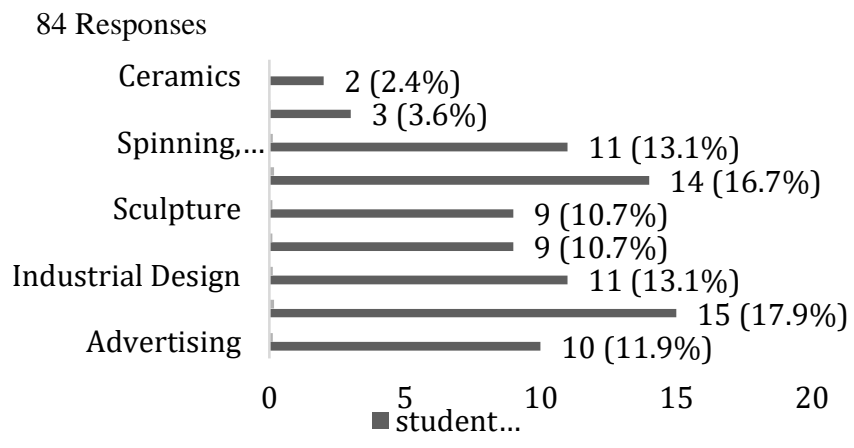

Fig. 8. Number of responses from the enrolled students.

In the question about the difficulties level of installing the program, almost $89 \%$ students found that it was easy for them. The next question was about the difficulties level of entering the course code and joining the classroom program. Almost $90 \%$ found that it was easy for them. As for students' preference for the type of device used to access the content of the course in the learning process, almost $94 \%$ preferred mobile phones. The next question was about the students' responses to evaluating the extent of commitment and regularity in the dates of publishing the scientific material within the classroom; almost $72 \%$ found it was an excellent one. As for students' responses to the evaluation for that E-learning process, almost $72 \%$ found it was an excellent one. The next question was about the students' responses to evaluating the response of the lecturer and his interaction with the students' proposals; almost $60 \%$ found it was an excellent one. The students' responses to the evaluation for the difficulties percentage that was encountered by the student during the process of learning and dealing with the program; almost $96 \%$ found it was easy. The next question was about the students' opinions on a proposal to generalize this experience in other educational materials; almost $65 \%$ agreed to the proposal. After summarizing suggestions of the 84 responses out of 129 students enrolled in the course, the main important opinions were as follows. Detailed audio explanation for the video exercise recording needs to be added. The exercises' color in the videos need to be changed to only light colors for better visibility. Finally, almost $60 \%$ preferred the integrated system according to the last question about the students' opinions on the effectiveness of using the E-learning technology side by side of the lectures.

\section{$5 \quad$ Findings and Suggested Framework for Integrated Engineering Courses}

The purpose of the study was to examine the effects of Google Classroom on teaching Engineering Perspective course for the first-year students in the faculty of Applied Arts, Damietta University. The results showed that the enrolled students have increased their ability to understand the course content easily. Their ability to access 
online lectures has increased compared to using handbooks and printed materials. Results also show that students had positive responses to the survey regarding their teaching and learning of Engineering Perspective using Google Classroom. The result analysis of the evaluation shows that students confirmed the continuous positive effectiveness of the online course learning on the Engineering Perspective material and videos. They enjoyed the easy free access to the scientific course at anytime and anywhere.

According to the previous study, Figures 9 and 10 summarize the suggested framework which was developed to integrate E-learning with traditional approach on teaching Engineering Perspective course.

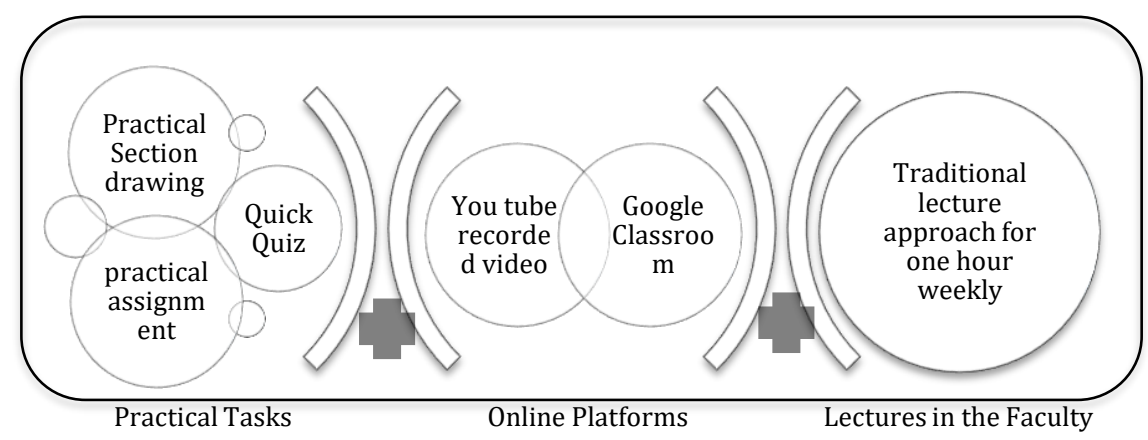

Fig. 9. The main points of E-learning integrated into the traditional pedagogical approach of the "Engineering Perspective" course.

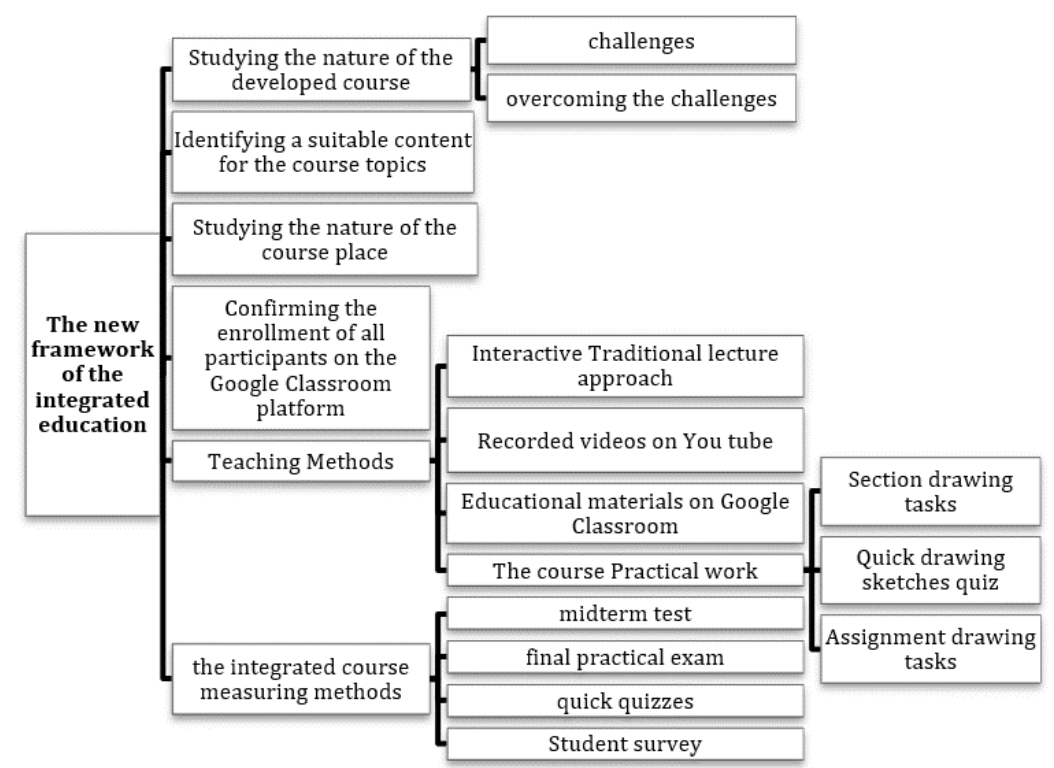

Fig. 10.The proposed framework for the integration of E-learning into the traditional approach 


\section{Conclusion and Recommendations}

The integrated approach objectives were to stimulate and promote more effective cooperation between instructors and students by using the students' smart phones in class activities. The new educational E-learning technology hones students' skills while offering the freedom of learning anytime, anywhere [34]. Students are becoming increasingly affine of innovative technologies and services, as there is tremendous scope to integrate technology with the education sector.

This study showed that integrating Google Classroom with Engineering Perspective course resulted in an increase of students' understanding of the content knowledge. Google Classroom may be considered as a program for resources in the classroom for teachers and students. Although the results demonstrated students' positive learning outcomes in Engineering Perspective drawings, their understanding of content knowledge had limited improvement. Further research is needed to validate the finding, especially to expand the sample size across different courses with different student populations. Technology provides a way to support content instruction, as well as an opportunity for teachers to be creative in developing class activities to engage students. More studies are needed to verify the use of technology and its benefit to students in the Engineering and Applied Arts faculties.

The analysis of feedback from students showed few subtle issues which lead to the improvement of the activity of the students and signify guidance for further process upgrades. Therefore, before organizing online courses, it is interesting to understand the needs and desires of the students. Until integrating technology with their classes, professors need to consider aspects such as socio - economic condition and level of IT experience, as well as gender and age [2]. Although there are measures that show the growing need for technology integration with one-on-one engineering courses, there are also some limitations that can be the topic of a new research. The new generation is prepared with a technological background, and a combined learning approach will be greatly helpful because it increases the level of learning and enhances access to education for learners [2]. This proposal can be developed in another research by activating student evaluation through the assignment part in Google Classroom so that the student can follow the development of his performance. Using the Google Classroom program via mobile by professors, the engineering drawings can be corrected.

That educational framework could be used during the COVID-19 time. The COVID-19 pandemic resulted in severe steps being taken to reduce the spread of the disease. Measures of social isolation and quarantine changed the behaviors of people, while the Internet played a significant role in promoting remote learning, e-teaching, online networking, gaming, video sharing, etc. [35]. The modernized methods of teaching that were illustrated in this paper help in achieving one of the 17 SDGs defined by the UN in the field of Education sustainability. 


\section{$7 \quad$ References}

[1] S. Freeman et al., "Active learning increases student performance in science, engineering, and mathematics," Proc. Natl. Acad. Sci. U. S. A., vol. 111, no. 23, pp. 8410-8415, 2014, doi: 10.1073/pnas.1319030111.

[2] A. A. Okaz, "Integrating Blended Learning in Higher Education," Procedia - Soc. Behav. Sci., vol. 186, pp. 600-603, 2015, https://doi.org/10.1016/j.sbspro.2015.04.086

[3] R. Kandakatla, E. J. Berger, J. F. Rhoads, and J. DeBoer, "Student perspectives on the learning resources in an Active, Blended and Collaborative (ABC) pedagogical environment," Int. J. Eng. Pedagog., vol. 10, no. 2, pp. 7-31, 2020, https://doi.org/10.3991 /ijep.v10i2.11606

[4] A. Hayashi, C. Chen, T. Ryan, and J. Wu, "The Role of Social Presence and Moderating Role of Computer Self Efficacy in Predicting the Continuance Usage of E-Learning Systems," J. Inf. Syst. Educ., vol. 15, no. 2, p. 5, 2020.

[5] H. Singh, S. Tyagi, and P. Kumar, Emerging Technology in Modelling and Graphics, vol. 937. Springer Singapore, 2020.

[6] M. Tzifopoulos, "In the shadow of Coronavirus : Distance education and digital literacy skills in Greece," vol. 5, no. 2, pp. 1-14, 2020.

[7] K. Khalaf, S. Balawi, G. W. Hitt, and M. A. M. Siddiqi, "Engineering Design Education: Effect of Mode of Delivery," Int. J. Eng. Pedagog., vol. 3, no. S2, p. 46, 2013, https://doi.org/10.3991/ijep.v3is2.2447

[8] S. Jacques, S. Bissey, and A. Martin, "Multidisciplinary Project Based Learning Within a Collaborative Framework," Int. J. Emerg. Technol. Learn., vol. 11, no. 12, pp. 36-44, 2016. https://doi.org/10.3991/ijet.v11i12.5996

[9] L. Alfaro, E. Apaza, J. Luna-Urquizo, and C. Rivera, "Identification of learning styles and automatic assignment of projects in an adaptive e-learning environment using project based learning," Int. J. Adv. Comput. Sci. Appl., vol. 10, no. 11, pp. 697-704, 2019, https://doi.org/10.14569/ijacsa.2019.0101191

[10] E. de S. Zancul, T. T. Sousa-Zomer, and P. A. Cauchick-Miguel, "Project-based learning approach: Improvements of an undergraduate course in new product development," Producao, vol. 27, no. Specialissue, pp. 1-14, 2017, https://doi.org/10.1590/0103$\underline{6513.225216}$

[11] G. Megahed, A. Elshater, and S. M. Z. Afifi, "Competencies urban planning students need to succeed in professional practices," Archnet-IJAR Int. J. Archit. Res., vol. ahead-of-p, no. ahead-of-print, 2019, https://doi.org/10.1108/arch-02-2019-0027

[12] K. Rathnam, A first course in engineering drawing. 2017.

[13] M. G. Violante and E. Vezzetti, "Implementing a new approach for the design of an elearning platform in engineering education," Comput. Appl. Eng. Educ., vol. 22, no. 4, pp. 708-727, 2014, https://doi.org/10.1002/cae.21564.

[14] L. M. Khodeir, "Blended learning methods as an approach to teaching project management to architecture students," Alexandria Eng. J., vol. 57, no. 4, pp. 3899-3905, 2018, https://doi.org/10.1016/j.aej.2018.10.004.

[15] E. S. Georgieva, A. S. Smrikarov, and T. S. Georgiev, "Evaluation of mobile learning system," Procedia Comput. Sci., vol. 3, pp. 632-637, 2011, https://doi.org/10.1016 j.procs.2010.12.106

[16] R. Hammad, "a H Ybrid E- L Earning F Ramework : P Rocess- B Ased ," University of the West of England, Bristol, 2018.

[17] A. Chatterjee, K. Ghosh, and B. Chatterjee, "A Study on Content Selection and CostEffectiveness of Cognitive E-Learning in Distance Education of Rural Areas," in 
Emerging Technology in Modelling and Graphics, 2020, pp. 783-786. https://doi.org/10.1007/978-981-13-7403-6_69

[18] L. Abazi-Bexheti, A. Kadriu, M. Apostolova-Trpkovska, E. Jajaga, and H. Abazi-Alili, "LMS Solution: Evidence of Google Classroom Usage in Higher Education," Bus. Syst. Res., vol. 9, no. 1, pp. 31-43, 2018, https://doi.org/10.2478/bsrj-2018-0003.

[19] B. Cestnik, M. Bohanec, and T. Urbančič, “QTvity: Advancing students' engagement during lectures by using mobile devices," ACM Int. Conf. Proceeding Ser., vol. 1008, pp. 334-341, 2015, https://doi.org/10.1145/2812428.2812467.

[20] S. Mehmood, "The Effects of Social Networking Sites on the Academic Performance of Students in College of Applied Sciences , Nizwa , Oman .," vol. 2, no. 1, pp. 111-125, 2013.

[21] S. Bhat, R. Raju, A. Bikramjit, and R. D'souza, "Leveraging e-learning through google classroom: A usability study," J. Eng. Educ. Transform., vol. 31, no. 3, pp. 129-135, 2018, doi: 10.16920/jeet/2018/v31i3/120781.

[22] D. Gubiani, I. Cristea, and T. Urbančič, "Introducing E-learning to a Traditional University: A Case-Study,” Stud. Syst. Decis. Control, vol. 208, pp. 225-241, 2019, doi: 10.1007/978-3-030-18593-0_18.

[23] J. Gaida, C. Seville, L. Cope, N. Dalwood, P. Morgan, and S. Maloney, “Acceptability of a blended learning model that improves student readiness for practical skill learning: A mixed-methods study," Focus Heal. Prof. Educ. A Multi-Professional J., vol. 17, no. 1, p. 3, 2016, https://doi.org/10.11157/fohpe.v17i1.116.

[24] P. Purg, K. Širok, and D. Brasil, "The Transformative Impact of Blended Mobility Courses," Int. J. Art Des. Educ., vol. 37, no. 2, pp. 187-198, 2018, https://doi.org/10.1111/jade.12101.

[25] K. M. DiCicco, "The effects of Google Classroom on teaching social studies for students with learning disabilities," College of Education, 2016.

[26] E. Railean, "Google Apps for Education - A powerful solution for global scientific classrooms with learner centred environment," Int. J. Comput. Sci. Res. Appl. Int. J. Comput. Sci. Res. Appl. ISSN, vol. 02, no. 02, pp. 19-27, 2012.

[27] N. Pugacheva, T. Kirillova, O. Kirillova, A. Luchinina, I. Korolyuk, and A. Lunev, "Digital paradigm in educational management: The case of construction education based on emerging technologies," Int. J. Emerg. Technol. Learn., vol. 15, no. 13, pp. 96-115, 2020, https://doi.org/10.3991/ijet.v15i13.14663.

[28] A. Richert, M. Shehadeh, F. Willicks, and S. Jeschke, "Digital Transformation of Engineering Education - Empirical Insights from Virtual Worlds and Human-RobotCollaboration," Int. J. Eng. Pedagog., vol. 6, no. 4, p. 23, 2016, https://doi.org/10.3991/ijep.v6i4.6023

[29] D. May, "Cross Reality Spaces in Engineering Education - Online Laboratories for Supporting International Student Collaboration in Merging Realities," Int. J. Online Biomed. Eng., vol. 16, no. 03, p. 4, 2020, https://doi.org/10.3991/ijoe.v16i03.12849.

[30] M. B. Nawaila and H. Bicen, "3D Technological Readiness: A Northern Cyprus Perspective," Int. J. Recent Contrib. from Eng. Sci. IT, vol. 5, no. 4, p. 19, 2017, https://doi.org/10.3991/ijes.v5i4.7737.

[31] K. Achuthan, P. Nedungadi, V. K. Kolil, S. Diwakar, and R. Raman, "Innovation adoption and diffusion of virtual laboratories," Int. J. online Biomed. Eng., vol. 16, no. 9, pp. 4-25, 2020, https://doi.org/10.3991/ijoe.v16i09.11685.

[32] L. Fewella, "An overview and full revision for Engineering perspective course (Interior + Exterior)," Engineering perspective course 2019-2020, 2020. [Online]. Available: https://www.youtube.com/watch?v=qRcQd rT84E\&feature=emb logo 
[33] L. Fewella, "Engineering Perspective List," Engineering perspective course 2019-2020, 2019.[Online].Available:https://www.youtube.com/playlist?list=PLFi0_156ml0iuT7pL73B 0v_G1M7L7a251.

[34] N. Phutela and S. Dwivedi, “A qualitative study of students' perspective on e-learning adoption in India," J. Appl. Res. High. Educ., 2020, doi: 10.1108/JARHE-02-2019-0041.

[35] T. Favale, F. Soro, M. Trevisan, I. Drago, and M. Mellia, "Campus Traffic and e-Learning during COVID-19 Pandemic," vol. 176, no. May, 2020.

\section{Authors}

Lina Nageb Fewella is a Lecturer $(\mathrm{PhD})$, Department of Interior Design and Furniture, Faculty of Applied Arts, Damietta University, Egypt. Till this date, she has published two scientific researches, two books from her thesis, one book on Islamic architecture and interior design, organized a national competition in her University, and acted as a reviewer in an international journal in 2019.

Laila Mohamed Khodeir is a Professor of Project Management and Sustainable Development in the British University in Egypt and at Ain Shams University, a certified Project Management Professional (PMP) from the PMI. Up to this date, she has published more than 45 papers either in peer reviewed journals, or in international conferences, in addition to publishing three book chapters, and acting as a reviewer in a number of national and international journals.

Abeer Hamed Swidan is a Professor of principles of Interior Design and Head of the Department of Interior Design and Furniture at Faculty of Applied Arts - Damietta University. She is a member of the Arab Society for Architecture and Islamic Arts. Dr. Abeer is the winner of the best award research through the activities of Hassan Fathy International Award for Architecture held through the Library of Alexandria for the years 2013-2014.

Article submitted 2020-08-16. Resubmitted 2020-11-06. Final acceptance 2020-11-08. Final version published as submitted by the authors. 